\title{
Application of Plant Growth Promoting Bacillus thuringiensis as Biofertilizer on Abelmoschus esculentus Plants under Field Condition
}

\author{
Sandip Bandopadhyay \\ Department of Microbiology Bidhannagar College, Government of West Bengal, EB - 2, Sector - 1, Salt Lake, \\ Kolkata - 700064 West Bengal, India.
}

\begin{abstract}
Plant growth promoting rhizobacterial strain Bacillus thuringiensis A5-BRSC was applied as charcoalbased biofertilizer on Abelmoschus esculentus plants under field condition for consecutive two years (spring-summer season). The objective of the present study is to evaluate the growth promoting parameters of the plant under field condition. Field application of biofertilizer showed statistically significant increase (at 0.05 levels by one-way ANOVA) in seed germination, shoot height, root length, leaf diameter, vigor index, fruit weight, seed weight and total fresh weight as well as dry weight of inoculated plants in comparison to the plants not treated with biofertilizer. Biofertilizer inoculated plants exhibited $68 \%$ more protein content in leaves, as well as about $70 \%$ more catalase and $52 \%$ more peroxidase activity than control plants; although leaf chlorophyll content was not significantly changed. Biofertilizer treatment increased nutritional content of the fruits. About $66 \%$ increase in the soluble sugar content, $34 \%$ more protein content and more than $75 \%$ phosphorus content in pods were noted in biofertilizer treated plants, compared to untreated plants.
\end{abstract}

Keywords: Abelmoschus esculentus, Bacillus thuringiensis, biofertilizer, field application, vigor index

*Correspondence: microbiosandip@gmail.com; 9831896029

(Received: March 07, 2020; accepted: April 06, 2020)

Citation: Bandopadhyay S. Application of Plant Growth Promoting Bacillus thuringiensis as Biofertilizer on Abelmoschus esculentus Plants under Field Condition. J Pure Appl Microbiol. 2020;14(2):1287-1294. doi: 10.22207/JPAM.14.2.24

(C) The Author(s) 2020. Open Access. This article is distributed under the terms of the Creative Commons Attribution 4.0 International License which permits unrestricted use, sharing, distribution, and reproduction in any medium, provided you give appropriate credit to the original author(s) and the source, provide a link to the Creative Commons license, and indicate if changes were made. 


\section{INTRODUCTION}

During the past five decades we have experienced the population explosion as well as an increase in agricultural development. Plant nutrition has played the central role in the gradual development of agriculture. The use of different chemical fertilizers, pesticides and herbicides in modern agricultural practice adversely affects on the growth rate of plants ${ }^{1,2}$. More over, they cause environmental pollution due to their toxic chemicals. Tremendous use of chemical fertilizers also creates environmental problems such as degradation of soil health, water pollution in surface and ground level, air pollution, change in biodiversity and suppressed ecosystem function ${ }^{3,4}$. In contrast, organic fertilizers help to maintain soil moisture, make available the necessary macronutrients in an acceptable form and release nutrients in a slower and more even manner. The most potent organic fertilizers are biofertilizer, which is the culture of microorganism or a group of microorganisms such as bacteria, fungi or algae, packed in an inert carrier material ${ }^{5}$. In the form of the biofertilizer, these microorganisms multiply in the soil and help in the atmospheric nitrogen fixation, phosphate solubilization, phytohormone secretion etc., there by take part in plant growth promotion.

Rhizosphere soil contains extensive population of such Plant Growth Promoting Rhizobacteria (PGPR) that are involved in the interaction with different plant roots, resulting in the promotion of the growth rate of plants and in some cases it enhances germination of plant seeds $s^{6,7}$. The plant growth promoting effects of different species of Bacillus, including Bacillus thuringiensis was well studied in last two decades. It has been reported that $B$. thuringiensis showed much higher rate of phosphate solubilization apart from its biopesticide activity ${ }^{8}$. Some of the phosphate solubilizing strains like Bacillus weihenstephanensis was reported as a good phosphate solubilizer with additional properties like heavy metal and antibiotic resistant as well as phytohormone producing strains ${ }^{9}$. It has been studied that combined inoculation of $B$. thuringiensis KR1 with Bradyrhizobium japonicum enhanced shoot weight, root weight, number of nodules, root volume and total biomass of soybean plants ${ }^{10}$. The strain $B$. thuringiensis KR1 was also reported to increase the dry weight of pea and lentils when it was co-inoculated with nitrogen fixing bacteria Rhizobium leguminosarum ${ }^{11}$. B. thuringiensis was proved to increase drought tolerance and oxidative metabolism of Lavandula plants, when it was co-inoculated with mycorrhiza under pot conditions ${ }^{12}$. B. thuringiensis can colonize not only with the leguminous plants like pea or lentils, but can colonize with rice, cabbage and cotton as endophytes ${ }^{13,14}$. It was reported that $B$. thuringiensis can promote the growth of tomato plants by increasing fresh and dry weights of plants, root and shoot length, seed germination rate, along with its bio-control activity by decreasing the growth of tomato wilt Fusarium $\mathrm{sp}^{15}$.

Effect of biofertilizer was studied on numerous plants like cereal grains, vegetables, fruits and medicinal plants ${ }^{11-16}$. Abelmoschus esculentus is a common vegetable in tropical countries like India. The vegetable is a good source of vitamins, minerals, amino acids and dietary fibres ${ }^{17}$. The advantage of the plant is that it can be cultivated as garden vegetable in little space like pots, as well as on large fields. Moreover, the plant has annual life cycle and grows faster in tropical climatic condition ${ }^{18}$. Therefore, the plant has drawn the attention of the researchers to study the effects of biofertilizers either in pot condition or in field condition ${ }^{18-20}$.

The energy sources required for the synthesis of chemical fertilizer are natural gas, petroleum and coal. All these energies are nonrenewable and costly, but in case of biofertilizer, energy requirement is fulfilled by costless renewable energy sources like plant synthesized carbohydrates ${ }^{21-23}$. Therefore, from the view point of energy requirement, biofertilizer is more reliable than chemical fertilizer. Moreover, increasing demographic pressure and food demand requires the utilization of biofertilizer for crop production. Application of potent PGPR as biofertilizer may give better crop yield, which can fulfill the global problem of nutrition.

The growth promoting effects of the biofertilizer used in the present study was already investigated in pot condition ${ }^{20}$. The aim of the present study is to explore such beneficial effects of same biofertilizer in field condition, using Abelmoschus esculentus as test plants 
in comparison to the plants not treated with biofertilizer.

\section{MATERIALS AND METHODS \\ The inoculum}

Bacillus thuringiensis A5-BRSC, isolated from the agricultural land of North 24 Parganas district, West Bengal, India was used as inoculum ${ }^{24}$. Experimental design

A 5.0' X 10.0' sunny area was selected in our institutional garden to carry out the field experiment. The field experiment was carried out in the spring-summer season for consecutive two years. Each year, two sets of experiments were carried out (i.e., total four sets of experiments in two years) in between the months of February and May. Each time a set of 30 Abelmoschus esculentus plants were used for both inoculated and un-inoculated fields. Weeds were removed from the fields and daily watering was monitored for 15 days before sowing the seeds in the fields. The seeds of $A$ belmoschus esculentus were soaked in $1 \%$ sodium hypochlorite solution for 2 minutes and then washed with sterile water. The seeds of were then sowed in two rows in the field. A same area of plot was chosen for 'control' in the close vicinity of 'test' field. The field was predominately comprised of loamy soil $(\mathrm{pH}: 7.1)$ with well connected drainage system.

\section{Physicochemical analysis of Field soil}

Some physicochemical characteristics of the field soil samples including $\mathrm{pH}$, Electronic Conductivity ( $\mathrm{ds} / \mathrm{m})$, temperature were measured directly in soil suspension analyzer (Elico Ltd., India). Organic carbon (C, \%) was estimated by slightly modified method of Walkley and Black ${ }^{25}$. $5 \mathrm{~g}$ of soil sample was mixed with potassium dichromate $\left(\mathrm{K}_{2} \mathrm{Cr}_{2} \mathrm{O}_{7}\right)$ and concentrated $\mathrm{H}_{2} \mathrm{SO}_{4}$. The solution was swirled and allowed to cool. $0.1 \mathrm{ml}$ aliquot from the digested sample was mixed with $85 \%$ phosphoric acid to eliminate interference of $\mathrm{Fe}^{3+}$ ions. Excess $\mathrm{K}_{2} \mathrm{Cr}_{2} \mathrm{O}_{7}$ present in the solution was titrated against $0.5 \mathrm{~N}$ ferrous ammonium sulphate $\left[\mathrm{Fe}\left(\mathrm{NH}_{4}\right)_{2}\left(\mathrm{SO}_{4}\right)_{2}, 6 \mathrm{H}_{2} \mathrm{O}\right]$, using diphenylamine as indicator. Available phosphate $\left(\mathrm{P}_{2} \mathrm{O}_{5}, \mathrm{~kg} / \mathrm{ha}\right)$ content was determined by digesting the soil sample for overnight with equal volume of concentrated $\mathrm{H}_{2} \mathrm{SO}_{4}$ and $\mathrm{H}_{2} \mathrm{O}_{2}$, and the digested sample was spectrophotometrically measured at $470 \mathrm{~nm}$ by adding vanado-molybdate reagent.
Potassium content of the soil sample $\left(\mathrm{K}_{2} \mathrm{O}, \mathrm{kg} / \mathrm{ha}\right)$ was determined by using flame photometer.

\section{Application of Biofertilizer in the field}

Biofertilizer was prepared by growing the culture of Bacillus thuringiensis A5-BRSCin nutrient broth for 24 hours at $30 \circ \mathrm{C}$. The culture was centrifuged and the cell biomass $\left(2 \times 10^{6} \mathrm{CFU} /\right.$ $\mathrm{ml}$ ) was dissolved in $0.2 \mathrm{M}$ phosphate buffer $(\mathrm{pH}$ 7.2). $100 \mathrm{ml}$ of culture was mixed with $100 \mathrm{~g}$ of fine charcoal (the carrier), i.e. at 1:1 ratio $(\mathrm{w} / \mathrm{v})$ and applied in the planting furrow of the field. Biofertilizer was sprayed throughout the surface soil with the help of a sprayer after 24 hours of sowing of seeds. Control field was treated in the same manner, except the addition of biofertilizer. A fresh set of culture was inoculated in the same manner after 40 days of first inoculation.

\section{Study of plant growth promotion}

Morphological parameters of $A$. esculentus plants were measured in every 10 days intervals up to 60 days. All the morphological parameters were measured in triplicate sets and standard errors from the mean were calculated. Percentage of seed germination, root length and shoot length, number of leaves, area of leaves, flowering time, fresh weight and dry weight of the matured plants were noted both in control as well as in test plants. Number of germinated seeds was counted in both inoculated and un-inoculated fields after 7 days of applying biofertilizer. Vigor index (VI) was determined by measuring root length and shoot length of the seedlings and calculated by using the formula: $\mathrm{VI}=$ (mean root length + mean shoot length) $x \%$ of seed germination. Leaf area was calculated by using the formula: $\mathrm{k} x$ leaf length $\mathrm{x}$ leaf width, where $\mathrm{k}$ $=0.75^{5}$. Fresh weight of plants was measured after 60 days of growth. For dry weight determination, plant parts were separated and dried in hot air oven at $75^{\circ} \mathrm{C}$ for 48 hours.

\section{Studies on the biochemical activities of the plants} in field condition

The effect of biofertilizer was also studied by measuring biochemical parameters of the plants including leaf chlorophyll content and protein content, catalase and peroxidase activities in growing leaves, soluble sugar content, protein content and phosphorus content of fruits under field condition. 
Chlorophyll content of leaves was estimated by the method of Dere et al. ${ }^{26}$ with slight modifications. $1 \mathrm{~g}$ of young leaf from each plant was kept separately in $50 \mathrm{ml}$ each of the $95 \%$ di-ethyl ether, $96 \%$ methanol and $100 \%$ acetone. The mixture was taken in the homogenizer and homogenized at $2500 \mathrm{rpm}$ for 60 seconds. Homogenate was filtered and the filtrate was centrifuged at $3000 \times \mathrm{g}$ for 8 minutes. Chlorophyll $a$ and chlorophyll b content was determined by taking absorbance at $662 \mathrm{~nm}$ and $644 \mathrm{~nm}$ respectively.

Catalase and peroxidase activity of the leaves were estimated by Chance and Maehly methods ${ }^{27} .1 \mathrm{~g}$ of leaf samples were homogenized with $\mathrm{ml}$ of $0.1 \mathrm{M}$ phosphate buffer (kept in $4^{\circ} \mathrm{C}$ ), $\mathrm{pH}: 7.0$ and then it was centrifuged at $15000 \times \mathrm{g}$ for 15 minutes at $4^{\circ} \mathrm{C}$. The sample was diluted 5 times with the same buffer and the diluted sample was used as crude enzyme source. $1 \mathrm{ml}$ of this leaf extract was used as enzyme source for catalase, which was incubated with $100 \mu$ moles of $\mathrm{H}_{2} \mathrm{O}_{2}$ and $0.1 \mathrm{M}$ phosphate buffer ( $\mathrm{pH}: 7.0)$ at $35^{\circ} \mathrm{C}$ for 2 minutes. Residual $\mathrm{H}_{2} \mathrm{O}_{2}$ was titrated against 0.01 $\mathrm{N} \mathrm{KMNO} \mathrm{K}_{4}$ solutions. $1 \mathrm{ml}$ of diluted leaf extract was mixed with $50 \mu$ moles of pyrogallol, $0.1 \mathrm{M}$ phosphate buffer(pH: 7.0$)$ and $100 \mu$ moles of $\mathrm{H}_{2} \mathrm{O}_{2}$ (substrate). Reaction mixture was incubated at $35^{\circ} \mathrm{C}$ for 2 minutes and absorbance was taken at $410 \mathrm{~nm}$.

The leaf sample as well as fruit sample (homogenized and centrifuged by following same protocol as leaf sample) was partially purified by $60 \%$ ammonium sulphate saturation and the solution was kept at $4^{\circ} \mathrm{C}$ for overnight. Next day, the solution was centrifuged at $17000 \times \mathrm{g}$ for 25 minutes at $4^{\circ} \mathrm{C}$ to precipitate out the protein. Concentrated protein was re-suspended in $0.05 \mathrm{M}$ Tris buffer ( $\mathrm{pH}$ 7.4). Further purification was carried out by dialysis against the same buffer for 18 hours. Dialyzed protein was finally concentrated by lyophilization. Protein content of the leaf and fruit sample was estimated by Lowry's method ${ }^{28}$, using Bovine Serum Albumin as standard protein. $1 \mathrm{~g}$ of crushed fruit sample was homogenized and then it was centrifuged at $12,000 \times \mathrm{g}$ for 10 minutes at $30^{\circ} \mathrm{C}$. Pellet was discarded and the supernatant was taken as soluble sugar source. The sugar was estimated by Anthrone reagent ${ }^{29}$. Absorbance was measured at $620 \mathrm{~nm}$. Amount of soluble sugar present in per $\mathrm{g}$ of fruit was determined from the standard curve of glucose.

Phosphorus content of the fruit sample was estimated by heating the sample in the low flame of Bunsen burner till the contents get charred. The content was then transferred in muffle furnace and heated it at $550^{\circ} \mathrm{C}$ till it completely turned into white ash. The ash was mixed with dilute $\mathrm{HCl}$ and distilled water and warmed it in boiling water bath. The solution was then filtered with Whatman filter paper no. 40 and clear filtrate was used as phosphate source. Phosphate content was estimated by L-ascorbic acid method ${ }^{30}$.

\section{RESULTS}

Physico-chemical analysis of field soil revealed that the soil is slightly alkaline with high organic carbon and moderate phosphate and potassium content (Table 1).

Table 1. Physicochemical analysis of field soil

\begin{tabular}{lccccc}
\hline Soil type & $\mathrm{pH}$ & $\begin{array}{c}\text { Electronic } \\
\text { Conductivity }(\mathrm{ds} / \mathrm{m})\end{array}$ & $\begin{array}{c}\text { Organic C } \\
(\%)\end{array}$ & $\begin{array}{c}\mathrm{P}_{2} \mathrm{O}_{5} \\
(\mathrm{~kg} / \mathrm{ha})\end{array}$ & $\begin{array}{c}\mathrm{K}_{2} \mathrm{O}(\mathrm{kg} / \mathrm{ha}) \\
(\mathrm{kg} / \mathrm{ha})\end{array}$ \\
\hline Loamy soil & 7.5 & 0.35 & $1.52 \pm 0.35$ & $96 \pm 0.8$ & $263 \pm 0.3$ \\
\hline
\end{tabular}

Carrier-mediated (charcoal) biofertilizer application of Bacillus thuringiensis on Abelmoschus esculentus exhibited significant increase in shoot height, root length, fruit weight, protein content and total dry weight of plant. Biofertilizer treated plants showed significant increase in length, width and weight of fruits in comparison to control plants. Biofertilizer inoculation did not affect significantly in chlorophyll content of the inoculated plants in comparison to control plants (Table 2). Seed germination started 24 hours earlier in inoculated plants. $67.56 \%$ seeds were germinated in biofertilizer inoculated fields, where as $41.67 \%$ seeds were germinated in un- 
inoculated field. Vigor index was observed much higher in inoculated plants (311.68) than the plants of control field (117.34). Average root length of 7 days seedlings of inoculated plants were 1.6 times longer than un-inoculated ones, but average shoot length of un-inoculated plants were 1.07 times longer than biofertilizer inoculated plants (although the difference is not significant at 0.05 level by one-way ANOVA) [Fig.: 1(a)]. Matured plants of 60 days old showed 1.3 times longer shoot length and 1.3 times more thick shoot diameter. Experimental plants showed 1.5 times higher root length and higher number of lateral roots than control plants [Fig. 1(b)]. Leaf area was

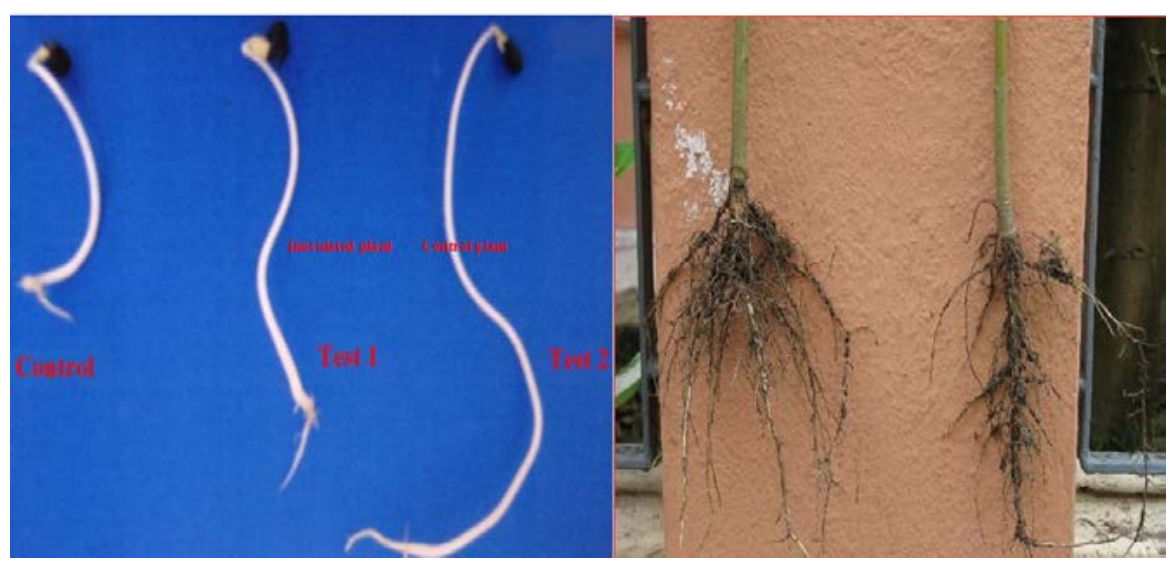

Fig. 1. (a) Germinated seedlings of 72 hours old Abelmoschus esculentus, where Test 1 and Test 2 are referred to as randomly chosen two inoculated seedlings against control, (b) Roots of both inoculated and un-inoculated 60 days old matured plant

Table 2. Comparison of morphological and biochemical activities of $A$. esculentus plants in both biofertilizer treated and un-treated field

\begin{tabular}{lll}
\hline Treatments & $\begin{array}{l}\text { Bacillus thuringiensis A5- } \\
\text { BRSC as biofertilizer in field }\end{array}$ & $\begin{array}{l}\text { Biofertilizer untreated } \\
\text { field }\end{array}$ \\
\hline No of plant studied/set of experiment & 30 & 30 \\
Leaf chlorophyll content (mg/cm2) & Chl.a: $1.097 \pm 0.38$ & \\
& Chl. b: $0.582 \pm 0.76$ & \\
Total Chl: $1.695 \pm 1.01$ & Chl.a: $1.115 \pm 0.35$ & \\
& Chl. b: $0.495 \pm 0.55$ & \\
Total Chl: $1.712 \pm 0.88$ & & $3.16 \pm 0.11$ \\
Leaf Protein content (mg/g leaf) & $5.325 \pm 0.32$ & $27 \pm 1.7$ \\
Leaf Peroxidase activity (U/g leaf) & $41 \pm 1.8$ & $104 \pm 1.2$ \\
Leaf Catalase activity (U/g leaf) & $176 \pm 0.89$ & $12 \pm 0.49$ \\
Average no. of fruits/ plant & $21 \pm 0.32$ & $13.53 \pm 0.52$ \\
Average Fruit weight (g) & $21.66 \pm 0.88$ & $(11.9 \pm 0.5) \times(5.6 \pm 0.12)$ \\
Fruit length \& width (cm x cm) & $(13.6 \pm 0.12) \times(6.82 \pm 0.24)$ & $41 \pm 0.55$ \\
Average no. of seeds/ fruit & $54 \pm 0.42$ & $2.17 \pm 0.34$ \\
Average seed weight (g) & $4.87 \pm 0.81$ & $2.04 \pm 0.09$ \\
Fruit Protein content (mg/g) & $2.75 \pm 0.09$ & $4.46 \pm 0.17$ \\
Soluble sugar content of fruit (mg/g) & $7.41 \pm 0.14$ & $1.21 \pm 0.08$ \\
Phosphorous content of fruit (mg/g) & $2.14 \pm 0.09$ & Root: $13.6 \pm 0.22 ;$ \\
Fresh weight of plant (g) & Root: $19.34 \pm 0.5 ;$ & Leaf: $27.3 \pm 0.62 ;$ \\
& Leaf: $42.25 \pm 0.6 ;$ & Stem: $42.19 \pm 0.5$, \\
& Stem: $58.02 \pm 0.42$, & Total:83.28 \\
& Total: $121.01 \pm 1.4$ & $14.8 \pm 0.11$ \\
Dry weight of plant (g) & $23.02 \pm 0.14$ & \\
& &
\end{tabular}


also significantly higher (1.52 times) than control plants [Fig. 2(a) \& (b)]. Rapid increase of shoot length and leaf area in biofertilizer treated plants than untreated plants was graphically illustrated in Fig. 3. Application of biofertilizer increased significant amount (at 0.05 levels by one-way ANOVA) of total dry weight as well as fresh weight of plants; increased protein content and enzymatic activities like catalase and peroxidase of leaves. However, total chlorophyll content did
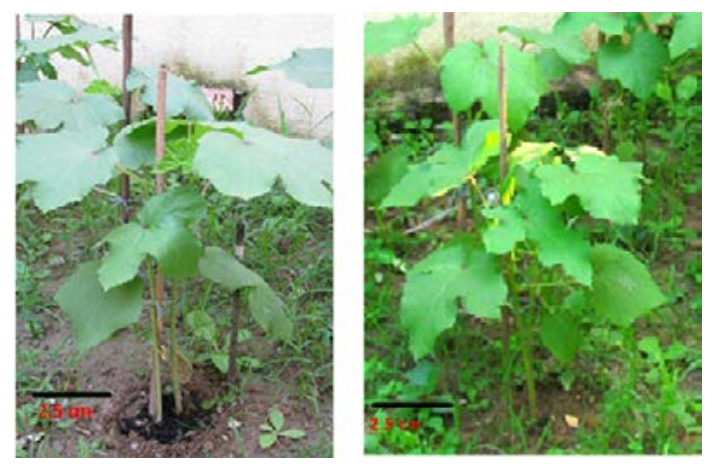

Fig. 2. Appearance of Abelmoschus esculentus leaves in (a) Biofertilizer-inoculated plants and in (b) uninoculated 'control' plants (Scale bar: $2.5 \mathrm{~cm}$ )

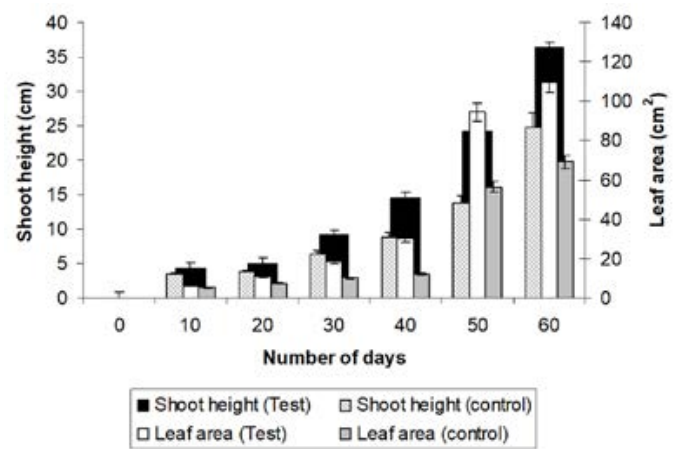

Fig. 3. Comparative analysis of shoot length and leaf area of $A$. esculentusplants in biofertilizer treated and un-treated plants under field condition

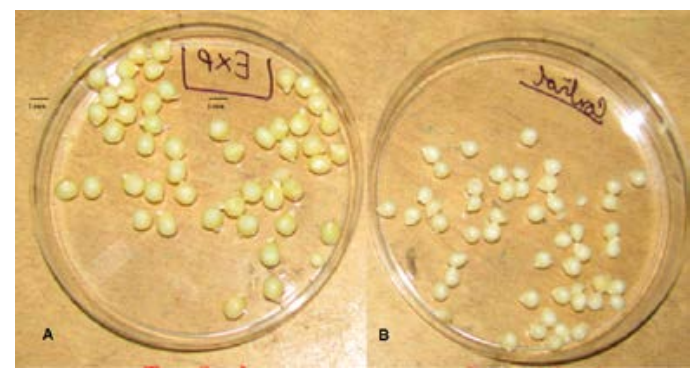

Fig. 4. Comparison of $A$. esculentusseeds from - (A) biofertilizer treated and (B) untreated plants(Scale bar: $1 \mathrm{~mm}$ ) not changed much (statistically no significant at 0.05 levels by one-way ANOVA) in comparison to un-inoculated plants (Table 2). Biofertilizer inoculation upgraded nutritional content of fruits in comparison to control. Protein content, soluble sugar content and phosphorous content of the pods were significantly increased (statistically significant at 0.05 levels by one-way ANOVA) in biofertilizer treated plants compared to controls (Table 2).

\section{DISCUSSION}

Bacillus thuringiensis has been reported to exhibit several growth accelerating activities like phosphate solubilization, phytohormone production, siderophore production etc ${ }^{8,12,31}$. The bacterial strain used in the present study was previously reported to exhibit an appreciable amount of phosphate solubilizing and phytohormone producing activity, as well as stimulated the growth of potted plants ${ }^{20,24}$. The focus of the present study is therefore, to elucidate its growth promotion activities as biofertilizer under field condition. Biofertilizer inoculation was accelerated not only increase in the root length and shoot height of Abelmoschus esculentus plants; but it increased the rate of seed germination, fresh weight as well as dry weight of the plants also. About $67 \%$ seeds were germinated in biofertilizer treated plants, where as only $41 \%$ seeds were germinated in controls. About $50 \%$ more fresh weight and dry weight was obtained in inoculated plants than control plants. Similar pattern of growth acceleration of $B$. thuringiensis was previously reported by Qi et al. in tomato plants ${ }^{15}$. Their study also revealed that $B$. thuringiensis not only accelerated percentage of seed germination; but accelerated fresh weight as well as dry weight of plants. Co-inoculation of $B$. thuringiensis with nitrogen fixing bacteria (NFB) was also reported to increase shoot weight, nodule numbers, root weight, root volume and plant biomass compared to solo inoculation of NFB as well as control ${ }^{10,11}$. Such type of positive effects of growth promoting rhizobacteria in different plants were also reported by various researchers in field condition $\mathrm{n}^{32-34}$ and our findings are quite consistent with the earlier findings.

Application of biofertilizer showed rapid increase in the weight of $A$. esculentus fruits as 
well as increased soluble sugar content, protein content and phosphorous content than the pods of control plants. Biofertilizer treated plants showed about $66 \%$ increase in the soluble sugar content, $34 \%$ more protein content and more than $75 \%$ phosphorus content in pods compared to untreated plants. Increase in nutritional content of $A$. esculentus by biofertilizer inoculation was previously reported by several researchers 18,19 . Sundari et $a l^{18}$. reported that single and dual inoculation of different plant growth promoting rhizobacteria in $A$. esculentus plants exhibited sugar content in a range of $3.66 \mathrm{mg} / \mathrm{g}$ to 5.92 $\mathrm{mg} / \mathrm{g}$ of fruit weight, where as in the present study the value is in the range of $7.41 \pm 0.14 \mathrm{mg} / \mathrm{g}$ of fruit weight. Their study showed that biofertilizer inoculation resulted in an increase of protein content of the fruit in a range of $1.55 \mathrm{mg} / \mathrm{g}$ to $1.89 \mathrm{mg} / \mathrm{g}$ of fruit weight. Our study showed that biofertilizer inoculation exhibited the protein content of $2.75 \pm 0.09 \mathrm{mg} / \mathrm{g}$ of fruit weight, which is quite impressive. Similar pattern of findings was reported by Kumar et al.19, although sugar content of fruits is quite high in our findings. Inoculation of $B$. thuringiensis was proved to increase nutritional content in pods of $A$. esculentus, the edible part of the plant, compared to control pods.

Biofertilizer treated plants showed higher numbers of fruits per plant, fruit weight, fruit length and width, as well as higher number of seeds and seed weight than control fruits. Similar findings were also reported by Sailaja ${ }^{25}$. Their findings suggested that the inoculation of Azospirillum caused significant increase in fruits per plant, fruit length, fruit weight and yield per plant. Datta et al. reported that co-inoculation of Bacillus and Streptomyces in chilli plant increased average plant height, plant canopy width, total number of fruits per plant, fruit weight and number of seeds. Therefore, the strain Bacillus thuringiensis A5-BRSC was proved to promote plant growth, increase nutritional value in the edible part of the plants as biofertilizer, and might be used in commercial scale in future for better crop yield in eco-friendly manner.

\section{ACKNOWLEDGMENTS}

The contribution of Dr. Swati Roy Gangopadhyay, Associate Professor, Department of Microbiology of Barrackpore Rastraguru Surendranath College, Kolkata - 700120 West Bengal, India is highly acknowledged by the author.

\section{FUNDING}

None.

\section{DATA AVAILABILITY}

All data are generated during present study and this data is included in this manuscript and/or supplementary files.

\section{ETHICS STATEMENT}

This article does not contain any studies with human participants or with any animals.

\section{REFERENCES}

1. Boldt TS, Jacobsen CS. Different toxic effects of the sulphonylurea herbicides metsulfuron methyl, chlorsulfuron and thifensulfuron methyl on fluorescent Pseudomonads isolated from an agricultural soil. FEMS Microbiol. Lett. 1998;161:29-35. https://doi. org/10.1111/j.1574-6968.1998.tb12925.x

2. Ahmed M, Khan MS. Effects of pesticides on plant growth promoting traits of Mesorhiobium strain MRC 4. J. Saudi Soc. Agr. Sci. 2012;11(1):63-71. https://doi. org/10.1016/j.jssas.2011.10.001

3. Socolow RH. Nitrogen management and the future of food: lessons from the management of energy and carbon. PNAS (USA). 1999;96:6001-6008. https://doi. org/10.1073/pnas.96.11.6001

4. Vance CP. Symbiotic Nitrogen Fixation and Phosphorus Acquisition: Plant Nutrition in a World of Declining Renewable Resources. Plant Physiol. 2001;127(2):390397. https://doi.org/10.1104/pp.010331

5. Gholami A, Shahsavani S, Nezarat S. The Effect of Plant Growth Promoting Rhizobacteria (PGPR) on Germination, Seedling Growth and Yield of Maize. World Acad. Sci. Engg. Technol. 2009;49:19-24.

6. Bashan Y. Inoculants of plant growth promoting rhizobacteria for use in agriculture. Biotechnol Adv. 1998;16:729-770. https://doi.org/10.1016/S07349750(98)00003-2

7. Atlas RM, Bartha R. Microbial ecology: Fundamentals and Applications, 1998; pp 281-324. Benjamin Cummings Publishing Company.

8. Seshadri $S$, Ignacimuthu $S$, Vadivelu $M$, Lakshminarasimhan $C$. Inorganic phosphate solubilization by two insect pathogenic Bacillus sp. Developments in Plant and Soil Sciences. First International Meeting on Microbial Phosphate Solubilization. 2003;351-355. https://doi. org/10.1007/978-1-4020-5765-6_56

9. Rajkumar $M$, Ying $M$ and Helena F. Characterization of metal-resistant plant -growth promoting Bacillusweihenstephanensisisolated from serpentine soil in Portugal. J. Basic Microbiol. 2008;48(6):500-508. 
https://doi.org/10.1002/jobm.200800073

10. Mishra PK, Mishra S, Selvakumar G, Kundu S, Gupta HS. Enhanced soybean (Glycine max L.) plant growth and nodulation by Bradyrhizobiumjaponicum-SB1 in presence of Bacillus thuringiensis-KR1. Acta Agr. Scand. B - S P 2009;59(2):189-196. https://doi. org/10.1080/09064710802040558

11. Mishra PK, Mishra S, Selvakumar Bisht JK. Coinoculation of Bacillus thuringiensis-KR1 with Rhizobium leguminosarum enhances plant growth and nodulation of pea (Pisumsativum L.) and lentil (Lens culinaris L.). World J. Microbiol. Biotechnol. 2009;25(5):753-761. https://doi.org/10.1007/s11274-009-9963-z

12. Armada E, Probanza A, Roldan A, Azcon R. Native plant growth promoting Bacillus thuringiensis and mixed or individual mycorrhizal species improved drought tolerance and oxidative metabolism in Lavanduladentata plants. J. Plant Physiol. 2016;192:112. https://doi.org/10.1016/j.jplph.2015.11.007

13. Praca LB, Gomes ACMM, Cabral G, Martins ES, Sujii ER, Monnerat RG. Endophytic colonization by Brazilian strains of Bacillus thuringiensis on cabbage seedlings grown in vitro. Bt. Res. 2012;3:11-19.

14. Pindi PK, Sultana T, Vootla PK. Plant growth regulation of Bt-cotton through Bacillus species. 3 Biotech. 2014;4(3):305-315. https://doi.org/10.1007/s13205013-0154-0

15. Qi J, Aiuchi D, Tani M, Asano S, Koike M. Potential of entomopathogenic Bacillus thuringiensis as plant growth promoting rhizobacteria and biological control agents for tomato Fusarium wilt. Int J Env Agr Res. 2016;2(6):55-62.

16. Zarabi M, Alahdadi I, Akbari GA, Akbari GA. A study on the effects of different biofertilizer combinations on yield, its components and growth indices of corn (Zea mays L.) under drought stress condition. African J Agrl Res. 2011;6(3):681-685.

17. Gemede HF, Haki GD, Beyene F, Woldegiorgis AZ, Rakshit SK. Proximate, mineral and nutrient compositions of indigenous okra (Abelmoschus esculentus): implications for mineral bioavailability. Food Sci Nut. 2015;4(2):223-233. https://doi.org/10.1002/fsn3.282

18. Sundari US, Gandhi A. Effects of microbial inoculants on growth and yield of bhendi [Abelmoschus esculentus (L.) Moench] in field trial. Int J Adv Res Biol Sci. 2017;4(4):82-88.

19. Kumar V, Saikia J, Barik N. Influence of organic, inorganic and biofertilizers on growth, yield, quality and economics of okra [Abelmoschus esculentus (L.) Moench] under Assam condition. Int J Curr Microbiol App Sci. 2017;6(12):2565-2569. https://doi. org/10.20546/ijcmas.2017.612.297

20. Bandopadhyay S. Optimization of biofertilizer production and its application using pot culture technique. J Pure Appl Microbiol. 2019;13(4):21592167. https://doi.org/10.22207/JPAM.13.4.28

21. Alam G. A study of biopesticides and biofertilizers in Haryana, India, International Institute for Environment and Development: Sustainable Agriculture and Rural Livelihoods Programme, 2000; Gatekeeper Series no.
93:1-24.

22. Boraste A, Vamsi KK, Jhadav A, et al. Biofertilizers: A novel tool for agriculture. Int J Microbiol Res. 2009;1(2):23-31.

23. Mia MAB, Shamsuddin ZH, Wahab Z, Marziah M. Effect of plant growth promoting rhizobacterial (PGPR) inoculation on growth and nitrogen incorporation of tissue-cultured Musa plantlets under nitrogenfree hydroponics condition. Australian J Crop Sci. 2010;4(2):85-90.

24. Bandopadhyay S, Pal S, Gangopadhyay SR. Isolation and characterization of plant growth promoting Bacillus thuringiensis from agricultural soil of West Bengal. Res J Biotechnol. 2011;6(2):9-13.

25. Walkley A, Black IA. An examination of Degtjareff method for determining soil organic matter and a proposed modification of the chromic acid titration method. Soil Sci. 1934;37:29-37. https://doi. org/10.1097/00010694-193401000-00003

26. Dere S, Gunes T, Sivaci R. Spectrophotometric determination of chlorophyll $-A, B$ and total carotenoid contents of some algae species using different solvents.Turkish J Bot. 1998;22:13-17.

27. Chance B and Maehly AC. Assay of catalase and peroxidase. Methods Enzymol. 1955;2:764-775. https://doi.org/10.1016/S0076-6879(55)02300-8

28. Lowry DH, Rosebrough NJ, Farr AL, Randall RJ. Protein measurement with the Folin phenol reagent. I Biol Chem. 1951;193:265-275.

29. Plummer DT. An introduction to practical biochemistry, $3^{\text {rd }}$ ed., Tata McGraw Hill Publishing Co. Ltd., New Delhi, India, 1990.

30. Clesceri LS, Greenberg AE, Eaton AD. Standard methods for the examination of water and wastewater, $20^{\text {th }}$ ed. APHA-AWWA-WEF, Washington DC, 1998.

31. Wilson MK, Abergel RJ, Raymond KN, Arceneaux JEL, Byers BR. Siderophores of Bacillus anthracis, Bacillus cereus and Bacillus thuringiensis. Biochem Biophys Res Commun. 2006;348:320-325. https://doi. org/10.1016/j.bbrc.2006.07.055

32. Das PK. Effect of cyanobacterial biofertilizer on growth and biochemical characteristics of Vincarosea Linn. Res J Biotechnol. 2010;5(4):76-79.

33. Souza R, Ambrosini A, Passaglia AMP. Plant growth promoting bacteria as inoculants in agricultural soils. Gen Mol Biol. 2015;38: 401-419. https://doi. org/10.1590/S1415-475738420150053

34. Rokhzadi A, Asgharzadeh A, Darvish F, Mohammadi GN and Majidi E. Influence of plant growth-promoting Rhizobacteria on dry matter accumulation and yield of chickpea (Cicerarietinum L.) under field conditions, American-Eurasian J Agri Env Sci. 2008;3(2):253-257.

35. Sailaja SM. Effect of biofertilizers on growth and yield of okra (Abelmoschusesculentus L. Moench): Thesis, Acharya N.G. Ranga Agricultural University, Hyderabad, India, 2005.

36. Datta M, Palit R, Sengupta C, Pandit MK, Banerjee S. Plant growth promoting rhizobacteria enhance growth and yield of chilli (Capsicum annuumL.) under field conditions. Aust. J. Crop Sci. 2011;5(5):531-536. 